\title{
DEFINITION OF bactericidal action in disinfectants TO Mycobacterium tuberculosis
}

\section{Valery Golovko", Victor Kochmarskiy, Andrey Bondarchuk}

Kharkov State Zooveterinary Academy, Department of Epizootology and Veterinary Management, P/O Malaya Danilovka, Dergachovskiy rayon, Kharkiv, Ukraine

\section{Abstract}

One of the main directions in the system of prophylaxis and fight against tuberculosis of animals belongs to the disinfection. For each disinfectant, it is important to have the following: good solubility in water, to own the wide spectrum of antimicrobial action, not to reduce antimicrobial activity in the presence of organic matters and hard water, not to be toxic or low-toxic for people and animals, not to have an unpleasant smell, not to damage the decontaminated objects, to be proof at storage, accessible for transporting and application, and also economic when exposed in the environment. The purpose of the research was, to study a bactericidal action in new disinfectant, in relation to Mycobacterium. The first stage of study was on the bactericidal properties in potential disinfectant with atypical mycobacteria, type of $M$. fortuitum № 122. For this purpose preparations were done by following the "Javelle-Kleyd" and "Geksadekon" instructions. It was concluded that crop and biological methods have bactericidal activity in relation to Mycobacteria tuberculosis, bovine kind with disinfectants "Javelle-Kleyd" in concentration $0,1 \%$ and exposure of 30 minutes and 1 hour and "Geksadekon" in concentration $3 \%$ and exposure time of 5 hours. "Javelle-kleyd" and "Geksadekon" disinfectants in certain modes, are possible to apply for prophylactic and forced disinfection in happy and unhappy economies in relation to tuberculosis of animals.

Key words: disinfection, mycobacteria, concentration, exposure

\footnotetext{
${ }^{1^{*}}$ e-mail: zoovet-kharkov@mail.ru
} 


\title{
BAKTERICIDNO DEJSTVO DEZINFICIJENSA NA MYCOBACTERIUM TUBERCULOSIS
}

\author{
Valery Golovko, Victor Kochmarskiy, Andrey Bondarchuk
}

\section{Kratak sadržaj}

Jedan od najvažnijih činilaca sistema profilakse i borbe protiv tuberkuloze životinja jeste dezinfekcija. Za svaki dezinficijens je važno da ima dobru rastvorljivost $\mathbf{u}$ vodi, širok spektar antimikrobne aktivnosti, da nema smanjenu antimikrobnu aktivnost u prisustvu organskih materija i tvrde vode, da nije toksičan za ljude i životinje, da nema neprijatan miris, da ne oštećuje objekte koji se dezinfikuju, da se lako čuva, prenosi i aplikuje i da je ekonomičan prilikom primene. Cilj istraživanja je bio izučavanje baktericidne aktivnosti novih dezinficijensa u odnosu na mikobakterijum mikroorganizam. Prvi deo istraživanja se odnosio na baktericidna svojstva dezinficijensa na atipične mikobaterije, tipa $M$. fortuitum № 122 . Korišteni su preparati "Javelle-Kleyd" i "Geksadekon", pripremljeni prema uputstvu proizvođača. Zaključeno je da metode dezinfekcije koje su bile predmet istraživanja imaju baktericidnu aktivnost u odnosu na mikobakterijum uzročnika tuberkuloze, bovine tipa, sa dezinficijensima "Javelle-Kleyd" u koncentraciji $0,1 \%$ i za vreme izlaganja 30 minuta i 1sat i sa preparatom "Geksadekon" u koncentraciji $3 \%$ i vremenu izlaganja 5 sati. "Javelle-kleyd" i "Geksadekon" preparate u određenim razblaženjima i načinima upotrebe, je moguće primeniti u profilaksi na uročnika tuberkuloze kod životinja.

Kljućne reči: dezinfekcija, mikobacterijum, koncentracija, izlaganje

\section{INTRODUCTION}

One of the main directions in the system of prophylaxis and fight against tuberculosis of animals belongs to the disinfection.

Disinfection is a complex of measures, aiming on elimination of causative agents of infectious diseases of man and animals in an environment, namely: disinfection of the second link of epizootic chain - factors of transmission. These measures enable the destruction of pathogenic microorganisms in the environment, in order to break the epizootic chain and stop development of epizootic process (1). Disinfection should be planned as a part of the prophylactic and epizootic measures (2).

For each disinfectant, it is important to have the following: good solubility in water, wide spectrum of antimicrobial action, not to reduce antimicrobial 
activity in the presence of organic matters and hard water, not to be toxic or low-toxic for people and animals, not to have an unpleasant smell, not to damage the decontaminated objects, to be proof at storage, accessible for transporting and application, and also economic when exposed in the environment (3, $4)$.

In addition, during the preparation of a disinfectant, some hygienic terms are required. The disinfectant must not show a negative effect on animals and auxiliary personnel in the concentrations recommended for application. The preparation of the disinfectant must be without negative consequences and with no allergic or cumulative properties expressed (5).

For the elimination of causative agent for tuberculosis many facilities are offered in an external environment, but they do not answer to the requirements. Also, not enough of the bactericidal properties of the infectious agent for tuberculosis are studied so far (6). Therefore there was a requirement for the improvement of existing and for the development of more effective devices for disinfection (8).

\section{MATERIAL AND METHODS.}

The purpose of our researches was, to study a bactericidal action in new disinfectant, in relation to Mycobacterium. The study was done in SEC "Institute of experimental and clinical veterinary medicine", department of study on brucellosis and tuberculosis. Laboratory research was done according to the methodical recommendations "The order of testing of new disinfectants for veterinary practice" (7).

The first stage of study was on bactericidal properties in potential disinfected with atypical Mycobacteria, type of $M$. fortuitum № 122. For this purpose the preparations were done by the following "Javelle-Kleyd" and "Geksadekon" instructions.

The exposure of bactericidal properties to atypical Mycobacteria were done in the study with the analysis of bactericidal action of the disinfectant to the causative agent of tuberculosis, bovine kind. The test was carried out with the laboratory culture strain of Vallee. Biological research was performed according to the «Settings on diagnostics of tuberculosis of animals and birds» ratified on 26.05 .1997 (9).

The estimation of the results gained during the study on bactericidal properties of disinfectant was done based on the results of crop and biological research. 


\section{RESULTS}

Results which are presented in Table 1 verify that analysis with different modes of disinfectant "Javelle-Kleyd" are the following:

- For the concentration of $0,05 \%$ and exposure time 1 hour and

- For the concentration of $0,1 \%$ and exposure time 30 minutes, 1 hour, the preparation disinfects atypical Mycobacteria.

- With the disinfectant "Geksadekon", the results were the following:

- For the concentration of $3 \%$ and exposure time 3 hours and 24 hours, the preparation disinfects atypical Mycobacteria.

Therefore, as next step, we conducted research with the test culture of bovine kind. The results of this exposure are given in Table 2 .

Table 1. Results of research of bactericidal action of antimicrobials in crops, related to M. Fortuitum №122

\begin{tabular}{|c|c|c|c|c|}
\hline \multirow{2}{*}{$\begin{array}{l}\text { Preparation } \\
\text { (disinfectant) }\end{array}$} & \multicolumn{2}{|c|}{ Mode of application } & \multicolumn{2}{|c|}{ Findings } \\
\hline & $\begin{array}{c}\text { Concen- } \\
\text { tration }\end{array}$ & Exposure & $\begin{array}{l}\text { Experimen- } \\
\text { tal group }\end{array}$ & Control \\
\hline \multirow{3}{*}{ "Javelle-Kleyd" } & $0,03 \%$ & $\begin{array}{c}15 \text { minutes } \\
30 \text { minutes } \\
1 \text { hours }\end{array}$ & $\begin{array}{l}+ \\
+ \\
+\end{array}$ & $\begin{array}{l}+ \\
+ \\
+\end{array}$ \\
\hline & $0,05 \%$ & $\begin{array}{c}15 \text { minutes } \\
30 \text { minutes } \\
1 \text { hours } \\
\end{array}$ & $\begin{array}{l}+ \\
+ \\
- \\
\end{array}$ & $\begin{array}{l}+ \\
+ \\
+ \\
\end{array}$ \\
\hline & $0,1 \%$ & $\begin{array}{c}15 \text { minutes } \\
30 \text { minutes } \\
1 \text { hours } \\
\end{array}$ & $\begin{array}{l}+ \\
- \\
- \\
\end{array}$ & $\begin{array}{l}+ \\
+ \\
+ \\
\end{array}$ \\
\hline \multirow{3}{*}{ "Geksadekon" } & $2 \%$ & $\begin{array}{l}1 \text { hours } \\
5 \text { hours } \\
24 \text { hours }\end{array}$ & $\begin{array}{l}+ \\
+ \\
-\end{array}$ & $\begin{array}{l}+ \\
+ \\
+\end{array}$ \\
\hline & $3 \%$ & $\begin{array}{c}1 \text { hours } \\
5 \text { hours } \\
24 \text { hours }\end{array}$ & $\begin{array}{l}+ \\
- \\
- \\
\end{array}$ & $\begin{array}{l}+ \\
+ \\
+ \\
\end{array}$ \\
\hline & $5 \%$ & $\begin{array}{l}1 \text { hours } \\
5 \text { hours } \\
24 \text { hours }\end{array}$ & $\begin{array}{l}- \\
- \\
-\end{array}$ & $\begin{array}{l}+ \\
+ \\
+\end{array}$ \\
\hline
\end{tabular}

Legend: "+" - growth of Mycobacteria is present; "-" growth of Mycobacteria is not present. 
Table 2. Crop method of determination of bactericidal properties in "Javelle-Kleyd" and "Geksadekon" disinfectants, in relation to the causative agent of tuberculosis, bovine type /strain of Vallee/

\begin{tabular}{|c|c|c|c|c|c|}
\hline $\begin{array}{c}\text { Preparation } \\
\text { (disinfectant) }\end{array}$ & Test-culture & $\begin{array}{c}\text { Concen- } \\
\text { tration, \% }\end{array}$ & Exposure & $\begin{array}{c}\text { Experimen- } \\
\text { tal group }\end{array}$ & Control \\
\hline $\begin{array}{c}\text { "Javelle- } \\
\text { Kleyd" }\end{array}$ & M.bovis & 0,1 & $\begin{array}{c}30 \text { minutes } \\
1 \text { hours }\end{array}$ & - & - \\
\hline "Geksadekon" & M.bovis & 3 & $\begin{array}{c}5 \text { hours } \\
24 \text { hours }\end{array}$ & - & + \\
\hline
\end{tabular}

Legend: "+" - growth of Mycobacteria is present; "-" growth of Mycobacteria is not present.

Based on the information given in Table 2 , it can be seen that the preparation "Javelle-Kleyd" in concentration $0,1 \%$ and exposure of 30 minutes and 1 hour and also "Geksadekon" in concentration $3 \%$ and exposure of 5 and 24 hours inactivate Mycobacterium tuberculosis of bovine kind, within the laboratory conditions. The growth of test culture M.bovis was noticed in control test tubes with nourishing environment provided at that time. For confirmation of positive results for crop method, the experiment on laboratory animals was performed. Research results on guinea-pigs are given in Table 3.

Table 3. Biological determination of bactericidal action of disinfectants "JavelleKleyd" and "Geksadekon" to the causative agent of tuberculosis, bovine kind

\begin{tabular}{|c|c|c|c|c|c|c|c|}
\hline & & & \multicolumn{4}{|c|}{ Mode of application } & \multicolumn{2}{|c|}{ Research findings } \\
\cline { 4 - 8 } $\begin{array}{c}\text { Prepa- } \\
\text { ration }\end{array}$ & $\begin{array}{c}\text { Type of } \\
\text { animals }\end{array}$ & Amount & $\begin{array}{c}\text { Dose } \\
\left(\mathrm{cm}^{3}\right)\end{array}$ & $\begin{array}{c}\text { Concen- } \\
\text { tration, \% }\end{array}$ & Exposure & $\begin{array}{c}\text { Expe- } \\
\text { riment. } \\
\text { group }\end{array}$ & Control \\
\hline $\begin{array}{c}\text { "Javelle- } \\
\text { Kleyd" }\end{array}$ & $\begin{array}{c}\text { Guinea- } \\
\text { pigs }\end{array}$ & 3 & 1 & 0,1 & $\begin{array}{c}30 \text { mi- } \\
\text { nutes }\end{array}$ & - & + \\
\hline $\begin{array}{c}\text { "Geksa- } \\
\text { dekon" }\end{array}$ & $\begin{array}{c}\text { Guinea- } \\
\text { pigs }\end{array}$ & 3 & 1 & 3 & 5 hours & - & + \\
\hline
\end{tabular}

Note: "+" tubercular changes in guinea-pigs, "-" no tubercular changes in guineapigs 
Based on the information given in Table 3 , it can be seen that in the guineapigs from experimental groups, in the internal organs there were no characteristic changes related to tuberculosis changes that could be found. On the other hand, in the control group, in lost (?) laboratory animals, pathological changes were discovered, that can be characterized as typical for tuberculosis. It should also be marked, that when allergic test for tuberculosis was performed in guinea-pigs, the intradermal reactions to tuberculin were discovered in the animals from the control group.

\section{CONCLUSION}

1. Crop and biological methods have bactericidal activity in relation to Mycobacteria tuberculosis, bovine kind with disinfectants "Javelle-Kleyd" in concentration $0,1 \%$ and exposure of 30 minutes and 1 hour and "Geksadekon" in concentration $3 \%$ and exposure time of 5 hours.

2. "Javelle-kleyd" and "Geksadekon" disinfectants in certain modes, are possible to apply for prophylactic and forced disinfection in happy and unhappy economies in relation to tuberculosis of animals.

\section{LITERATURE}

1. About the order of test new disinfection facilities for veterinary practice: Methodical pointing. Gosagroprom of the USSR. M.: 90, 1987. (7)

2. Babaykin V., Vasilenko P.: Disinfection with the use of aerozoley - an important link is in a prophylaxis but liquidations of diseases of zoons. Veterinary medicine of Ukraine. 2, 4, 2000. (5)

3. Leadthrough of veterinary disinfection objects of stock-raising: Instruction. M.: Agropromizdat, 1989. - 61 p. (2)

4. Rusenko I.: New index of efficiency of disinfected facilities for sanitation of stock-raising apartments. Veterinary medicine of Ukraine.7, $39-40$, 2005. (3)

5. Selischeva N. V, M. V. Bogach, Y. V. Andrienko, V. P. Monastirli, O. A. Goncharuk: Monitoring of modern disinfectants in relation to the exciter of tuberculosis and atypical Mycobacteria Veterinary medicine of Ukraine. $2,5-7,2013$.

6. Setting is on diagnostics of tuberculosis of zoons and bird. - 1997. - 38 P. (9)

7. Volkov Y.P.: Prospects of development researches in an area of the development of disinfectants, Materials of scientific conference "Issues of the day disinfections, sterilizations, fumigations and deratizations". M.; P. 13 - 14.1992 (1) 
8. Zarickiy A. M.: Disinfection: desinfection facilities and their applications. Zhytomyr: PP «Ruta ». 1, 384, 2001. (6)

9. Yaschenko M. F.: Desinfection of stock-raising apartments bactericidal suds: Scientific announcer NAU. 36, 172 - 174, 2001 (4)

Received / Primljeno: 15.11.2013.

Accepted / Odobreno: 08.12.2013. 